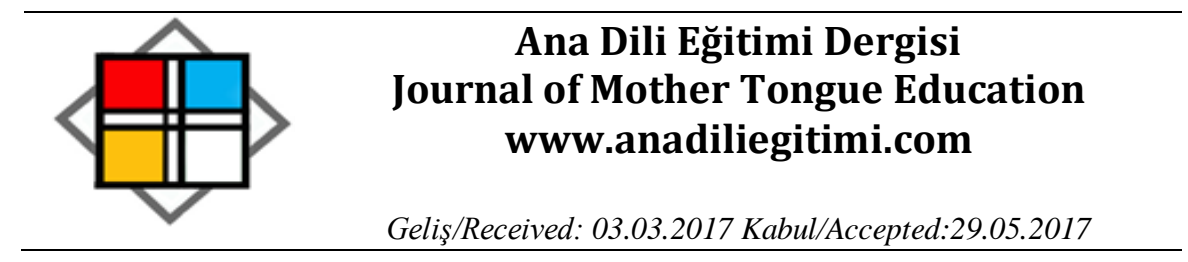

\title{
Hikâye Kartlarının Çocukların Görsel İfade Becerileri Üzerindeki Etkisi
}

\author{
Ahmet $A K C ̧ A Y^{*}$ \\ Nilüfer OKUR AKÇAY**
}

Öz

Okul öncesi dönem, çocuğun çevresinde olan olayları anlamlandırmaya çalıştığı bir dönemdir. Bu dönemde çocukların ilköğretim süreci için okumaya ve yazmaya hazırlanması, okuduklarını anlama ve dinlediklerini anlamlandırması gerekmektedir. Bu amaçla uygulanan hikâye okuma etkinlikleri önemli bir yere sahiptir. Hikâye anlatımında farklı teknikler mevcuttur. Bunlardan biri de hikâye kartları ile anlatımdır. Bu araştırma fen konularının öğretiminde hikâye kartlarının kullanımının çocukların görsel ifade becerileri üzerindeki etkisini belirlemek amacıyla yapılmıştır. Deney ve kontrol gruplu yarı-deneysel biçimde gerçekleştirilen çalışmanın örneklemini, 20152016 öğretim yılının güz döneminde Ağrı il merkezinde bulunan Milli Eğitim Bakanlığı'na bağlı anasınıfına devam eden 41 çocuk oluşturmaktadır. Rastgele olarak belirlenen öğrencilerden iki grup oluşturulmuştur. Araştırmada veri toplamak amacıyla araştırmacılar tarafından hazırlanan "Görsel ifade Değerlendirme Ölçeği" kullanılmıştır. Verilerin analizi için deney ve kontrol gruplarındaki çocukların uygulama öncesi ve sonrasında yaptıkları resimler değerlendirilmiştir. Elde edilen verilerin analizinde her iki grubun karşılaştırılmasında bağımsız gruplar $t$-testi kullanıımışır. Araştırma sonucunda hikâye kartlarının çocukların görsel ifade becerileri üzerinde etkili olduğu tespit edilmiştir.

Anahtar Kelimeler: Hikâye kartları, okul öncesi dönem, görsel ifade, fen

\section{The Effect of Story Cards on the Visual Expression Skills of the Children}

\begin{abstract}
The pre-school period is a period in which children try to make sense of the events happening around them. In this period, it is necessary for children to become ready to read and write, to understand what they read and to make sense of what they listen to for their primary school education. Story reading activities used for this purpose have a significant role. There are different techniques in storytelling. One of them is storytelling with story cards. This research was conducted to determine the effect of story cards on children's visual expression skills in the teaching of science subjects. The sample of the study carried out in the semi-experimental form with experimental and control groups was composed of 41 children who attended a Ministry of National Education governed kindergarten in the city of Ağrı in the fall term of 2015-2016 academic year. Two groups, consisting of randomly selected students, were formed. The "Visual Expression Evaluation Scale" prepared by the researchers was used to collect data in the research. For the analysis of the data, the pictures drawn by the children in the experimental and control groups were evaluated. In the analysis of the obtained data, independent samples t-test was used in the comparison of both groups. It was determined in the obtained data that the school story cards were influential on the visual expression skills of preschool children.
\end{abstract}

Keywords: Story cards, pre-school period, visual expression, science

\footnotetext{
${ }^{*}$ Yrd. Doç. Dr., Ağrı İbrahim Çeçen Üniversitesi Eğitim Fakültesi Türkçe Eğitimi ABD, turkolog_25@hotmail.com

${ }^{* *}$ Yrd. Doç. Dr., Ağrı İbrahim Çeçen Üniversitesi Eğitimi Fakültesi Okul Öncesi Eğitimi ABD, nilokur-7@hotmail.com
} 


\section{Giriş}

Okul öncesi dönem, çocuğun çevresinde olan olayları anlamlandırmaya çalıştığı, iletişim kurduğu, temel bilgi ve becerilerinin oluştuğu, yeni karşılaştıkları durumlara karşı merak duygularının geliştiği ve karşı karşıya kaldıkları sorunlara çözüm yolu arayabilecekleri bir dönemdir. Bu dönemde çocuk içinde bulunduğu toplumun değerlerini ve kültürlerini de kazanarak kişiliğinin temellerini atar (Ömeroğlu ve Yaşar, 2005). Çocuğun eğitim hayatının başlangıcı sayılabilecek bu dönem; sosyal, dilsel, zihinsel vs. gelişim açısından büyük bir öneme sahiptir.

Okul Öncesi Eğitim Programlarında okuma-yazma öğretimine yönelik hedef ve amaçlar yer almamaktadır. Ancak çocukların ilköğretim süreci için okuma ve yazmaya hazırlanması ve okuduklarını veya dinlediklerini anlamlandırmaları gerekmektedir. Okul öncesi dönemde çocuğa zengin uyarıcılar sunulması, onun hayal gücünün artmasını ve düşünme becerilerinin gelişmesini sağlar. Özellikle hayali kahramanlar, oyunlar ve dinleme etkinlikleri çok önemlidir (Çağdaş, Albayrak ve Cantekinler, 2003). Okul öncesinde çocukların okuma-yazmaya hazırlık yapabilmeleri için uygulanan hikâye okuma etkinlikleri ise çocuklara zengin bir hayal dünyası sunmakta ve dinlenenlerin zihinlerinde canlandırımasına katkı sağlamaktadır.

Hikâye, yaşanmış ya da yaşanması muhtemel olayların çoğunlukla zaman, mekân ve kahraman/lar bağlamında kısa biçimde anlatıldığı bir metin türüdür. Hikâye kitaplarının okunması veya hikâyelerin çocuklara anlatımı, çocuğun kendini ve çevresini tanımasına ve bu çevre ile sağlıklı ilişkiler kurmasına olanak sağlarken, algılama ve yorumlama yeteneğinin gelişimini de destekler (Bağdaş ve Demir, 2016). Hikâye okumak, çocukların çeşitli açılardan gelişimlerinde rol oynar. Küçükturan (2004) hikâye okumanın önemini şu şekilde sıralamıştır:

Çocukların okuma ve yazmaya karşı olumlu tutum geliştirmelerini sağlar,

> Çocukların hoşça vakit geçirmelerini sağlar,

> Hikâyenin çocuğa yeniden anlattırılması, çocuğun hikâyenin hangi kısmına odaklandığını ve hikâyenin hangi kısmından hoşlandığının anlaşıımasını sağlar,

$>$ Çocuğun hikâyedeki hangi dilbilgisi kurallarına ve sözcüklerine dikkat edip kullandığını ortaya koyar,

> Çocuğun bilişsel kavramlar hakkında bilgi edinmesine ve öğrenmesine katkıda bulunur,

Hikâyenin anlatılması sırasında çocuğun kendi deneyimlerini de aktarması, onlar ve aileleri hakkında bilgi edinilmesini sağlar, 
Görsel belleğin güçlenmesine, ses bilgisinin artmasına ve duygudaşlık kurmaya yardımcı olur.

Hikâye anlatımında farklı teknikler mevcuttur. Bunlardan biri de hikâye kartları ile anlatımdır. Hikâye kartları, çoğunlukla kare veya dikdörtgen biçiminde hazırlanan, çocuklara anlatılan bir hikâyenin görsel olarak sunulmasına katkı sağlayan, olay, kişi/kişiler, mekân veya zaman gibi hikâyeyi oluşturan ögelerin anlaşılmasına aracılık eden araçlardır. Hikâye kartlarının etkili olabilmesi için belli şartları sağlamaları gerekmektedir. Kartlardaki resimlerin çocukların görebileceği büyüklükte olması, kartların kartonlarla sertleştirilmesi, anlatım sırasında sağa sola bükülmemesi, kartlara çizilen resimlerin boyalarla renklendirilmesi ve resimlerin hikâyede geçen olayı ve karakterleri iyi bir şekilde yansıtması hikâye kartlarında yer alması gereken temel niteliklerdir (Bektaş, 2010). Çeşitli boyutlarda kullanılması mümkün olan hikâye kartlarının, çocukların resimleri rahatlıkla görüp anlayabilecekleri boyutlarda ve ortalama olarak 30x30 cm olarak hazırlanması gerekir (Ural, 1985).

Hikâye kartlarının hazırlanması anlatılan hikâyenin içeriğine göre değişmektedir. Çocukların hikâyeyi tam ve doğru biçimde anlamaları için gerekli sayıda kartın hazırlanması gerekmektedir. Hikâyenin konusu doğrultusunda hazırlanmış olan kartların arkasına numaralar verilmeli ve bu numara sırasına göre kartlar çocuklara gösterilmelidir. Hikâye metinleri ise kartların arkasına yazılmadan farklı bir belge üzerine kaydedilmelidir (Aral, Kandır ve Yaşar, 2000). Öğretmen hikâye anlatırken eş zamanlı olarak hikâye kartlarını öğrencilere göstermeli, ayrıca gerektiğinde kartları çocuklara vererek kendi öykülerini anlatmalarına destek olmalıdır (Saatli, 1997). Uygulanan hikâye etkinlikleri, çocuklara, problem çözme, hayal güçlerini ortaya koyma, yaratıcılıklarını geliştirme, iç dünyalarındaki yaşantıları yansıtma olanağı sağlamalıdır (Zembat ve Zülfikar, 2006).

Dış çevrede olan bitenin algılanması için gerekli fen becerilerinin temelleri okul öncesi dönemde atılmaktadır. Çocukların bu yaşlarda fen ve doğaya yönelik ilgileri, ilerideki yaşamlarını da etkileyecektir (Yaşar, 1993). Bu doğrultuda çocukların öğrenirken zevk alacağı ve fen derslerindeki konulara karşı olumlu tutum geliştireceği şekilde öğretim ortamını düzenlemek gerekmektedir (Turgut ve Kışla, 2015). Fen konuları çoğunlukla soyut kavramlar içermektedir (Çınar, 2013). Dolayısıyla bu konuların somutlaştırılması ve görselleştirilerek çocukların öğrenebilecekleri bir biçimde öğretilmesi gerekmektedir (Okur Akçay, 2014; Şahin, 2016). Fen konularının öğretiminde özellikle kavramları veya kavramlar arası ilişkilerin aktarımında hikâye kartlarının kullanılması öğretmenlere büyük kolaylıklar sağlamaktadır (Demircioğlu, Demircioğlu ve Ayas, 2006). Bu açıdan, fen konularının görselleştirilmesinde hikâye kartlarından yararlanılması gerekmektedir.

Hikâye kartlarında yer alan resimler aracılığıyla çocuklara somutlaştırarak eğitim yaparken, bu kartların kullanımı sonrasında çocuklara çizdirilecek resimlerle de çocukların konuyu kavrama 
durumlarını değerlendirmek mümkündür. Çünkü çocuk resimleri, çocukların psikolojik durumları, psiko-motor yetenekleri, bilgi düzeyleri ve görsel ifade becerileri ile ilgili durumlarını ortaya koymaktadır (Aksoy ve Baran,2010; Doğru, Turcan, Arslan ve Doğru 2006; Erten, 2003). Bu açıdan eğitimsel ve psikolojik değerlendirmelerde resimlerden sıklıkla yararlanılmaktadır.

Hikâyeler ile fen konularının öğretimi üzerine çeşitli çalışmalar yapılmıştır. Kahraman ve Karataş (2012) bilim tarihi temelli hikâyeler ile fen konularının öğretiminin öğrencilerin öğrenme düzeylerine büyük katkılar sağladığını saptarken, Cındıl, Özmen ve Ünal (2012), fen dersi ile ilgili kavramların öğretiminde hikâyelemenin öğrenci başarılarına etkide bulunduğunu ve kavramların anlaşıımasına katkı sağladığını belirlemiştir. Ekici ve Pekmezci (2013)'nin çalışmasında bilişim teknolojileri temelli hikâyelerin fen derslerinde öğrencilerin başarılarını olumlu yönde etkilediği belirlenmiştir. Tao (2003) tarafından yapılan çalışmada, hikâyeler aracılığıyla sürdürülen öğretim faaliyetlerinin öğrencilerin bilimin doğası hakkındaki görüşleri üzerindeki etkisini incelenmiştir. Araştırma sonucunda öğrencilerin bilimin doğasına ilişkin görüşlerinin değiştiği sonucuna varılmıştır. Karweit ve Wasik (1996) çocuklar üzerinde yaptıkları araştırmada hikâye kitaplarının çocukların anlama becerileri üzerinde etkiye sahip olduğu belirlenmiştir. Akçay, Özyurt ve Akçay (2014) tarafından yapılan çalışmada fen ve teknoloji dersinde içinde hikâye yazmanın da olduğu çoklu yazma etkinlikleri kullanımının öğrenci başarısı ve kavram öğrenmeye katkısı açısından pozitif yönde etkide bulunduğu tespit edilmiştir. Ören ve Yılmaz (2013) bilimsel hikâye temelli hikâyelerin fen ve teknoloji dersinde kullanımına dönük rehber materyal tasarlamışlardır. Yapılan alan yazın incelemesinde, soyut olan fen kavramlarının öğretiminde hikâyelerin kullanımı üzerine çalışmaların sıklıkla yapıldı̆̆ı fakat fen öğretiminde hikâye kartlarının kullanımının çocukların görsel ifade becerilerine etkisi üzerine bir çalışma gerçekleştirilmediği belirlenmiştir. Bu araştırma, çocukların öğrenebilecekleri temel düzeydeki fen konularının öğretiminde hikâye kartlarının kullanımının görsel ifade becerileri üzerindeki etkisini tespit edebilmek amacıyla gerçekleştirilmiştir.

\section{Yöntem}

$\mathrm{Bu}$ araştırmada, deney ve kontrol gruplu yarı-deneysel yöntem kullanılmıştır. Yarı deneysel yöntem, deneysel çalışmalarda deney ve kontrol gruplarının rastgele oluşturulmasının çok güç veya olanaksız olduğu durumlarda, önceden oluşturulmuş sınıfların kullanılmasıyla gerçekleştirilen bir yöntemdir (Robson 1998; akt. Özmen ve Kolomuç, 2004).

\section{Araştırmanın örneklemi}

Bu çalışmanın örneklemini, 2015-2016 öğretim yılının güz döneminde Ağrı il merkezinde bulunan Milli Eğitim Bakanlığı'na bağıı anasınıfına devam eden 41 çocuk oluşturmaktadır. Rastgele olarak belirlenen öğrencilerden oluşan iki grup oluşturulmuştur. Bunlar hikâye kartlarının uygulandığı 
grup [Deney Grubu (HKG) N=20] ve düz anlatım yönteminin kullanıldığı [Kontrol Grubu (KG) N=21] şeklinde belirlenmiştir.

\section{Verilerin toplanması}

Araştırmada veri toplamak için araştırmacılar tarafından hazırlanan "Görsel ífade Beceri Değerlendirme Ölçeği” kullanılmıştır. Ölçek, 5 ölçütü değerlendirmek üzere tasarlanmıştır. Bu ölçütler:

> Hikâyede yer alan kavramları çizebilme,

Hikâyede yer alan olayları oluş sırasına (kronolojik) göre sıraya koyabilme,

$>$ Kavramların şekillerini gerçeğe uygun çizebilme,

$>$ Kavramların renklerini gerçeğe uygun resmedebilme,

> Hikâyelerde geçen kavramları farklı kavramlarla özdeşleştirebilme,

Dereceli puanlama anahtarı biçiminde hazırlanan ölçek 5 dereceden oluşmuş ve her bir maddeden alınabilecek en fazla puan ise 20 olarak belirlenmiştir. Ölçeğin hazırlanış aşamasında biri okul öncesi eğitimi, biri Türkçe Eğitimi biri de ölçme-değerlendirme alanında olmak üzere 3 farklı uzmanın görüşüne başvurulmuş ve ölçme aracının geçerli olduğu ve ölçmek istenen niteliklere uygun olarak hazırlandığı sonucuna ulaşımıştır.

\section{Uygulama süreci}

Resimli hikâye kartlarının çocukların görsel ifade becerileri üzerindeki etkisinin belirlenmesini hedef alan bu araştırmada öncelikle çocukların seviyelerine uygun fen konuları seçilmiştir. Seçilen konulara yönelik hikâyeler yazılmış, bu hikâyelerin görsel olarak çocuğun ilgi ve ihtiyaçlarını karşılayacak nitelikte olmasına dikkat edilmiş ve hikâye kartları oluşturulmuştur. Hikâye kartlarının ebatı, $30 \mathrm{~cm} \times 40$ cm'dir. Hikâyeler ve hikâye kartları, okul öncesi eğitimi alanında uzman olan iki kişiye gösterilmiş ve araştırma için uygunluğu sağlanmıştır. Hikâyeler haftada bir ders saati kapsamında dört hafta süresince uygulanmıştır. Deney grubunda hikâye kartları kullanılarak hikâyeler anlatılmış, kontrol grubunda ise düz anlatım yöntemi kullanılmış ve çocuklara sadece hikâyeler okunmuştur. Araştırmada dört farklı uygulama gerçekleştirilmiştir. Uygulama konuları aşağıda yer almaktadır:

$>$ Vitaminlerin ziyareti,

> Mikroplar dünyası,

> Duygularım, 


\section{Suyun yolculuğu.}

Deney grubunda yapılan uygulamalarda, çocuklara sunulan resimli hikâye kartlarından örnekler, aşağıda dikkatlere sunulmuştur:
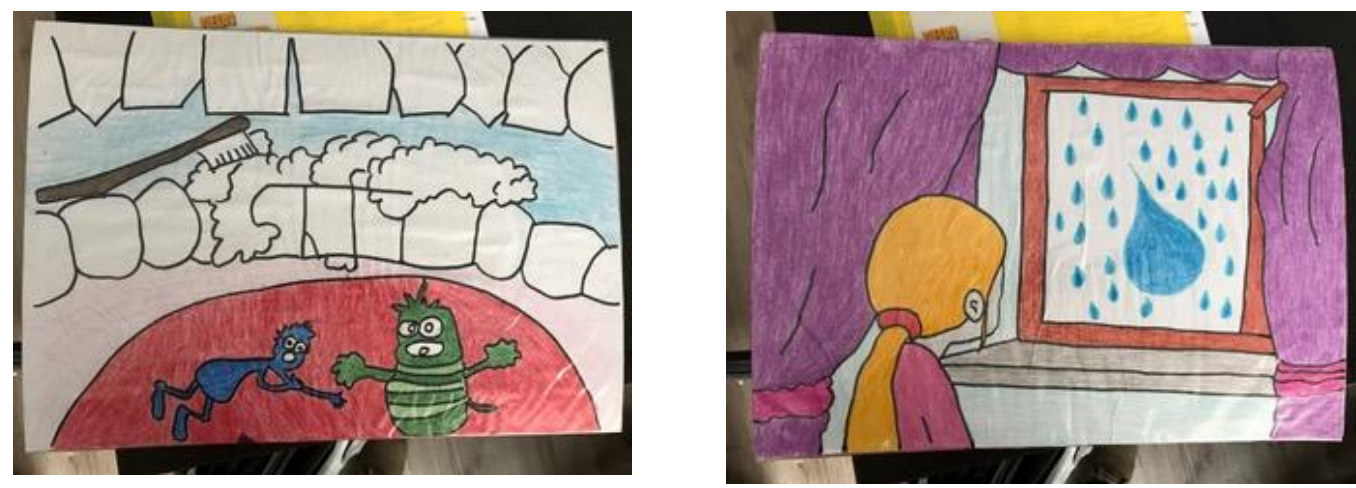

Şekil 1. Hikâye kartlarından örnekler

\section{Verilerin Analizi}

Verilerin analizi için deney ve kontrol gruplarındaki çocukların uygulama öncesi ve sonrasında yaptıkları resimler değerlendirilmiştir. Elde edilen verilerin analizinde her iki grubun karşılaştırılması için bağımsız gruplar t-testi kullanılmıştır.

\section{Bulgular}

\section{Mikropların Dünyası adlı uygulamadan elde edilen bulgular}

Uygulama öncesinde ve sonrasında deney ve kontrol gruplarında yer alan çocukların "Mikropların Dünyası” adlı uygulama için hazırladıkları resimlerin ölçekten almış oldukları puanlara göre ön test ve son test ölçümleri Tablo 1'de verilmektedir.

Tablo 1. Gruplara göre ön test-son test bağımsız t testi sonuçları

\begin{tabular}{lllccccc}
\hline Testler & Gruplar & $\mathbf{N}$ & $\mathbf{X}$ & ss & sd & $\mathbf{t}$ & $\mathbf{p}$ \\
\hline \multirow{2}{*}{ Ön test } & HKG & 20 & 55.33 & 12.28 & 39 & -1.107 & .275 \\
& KG & 21 & 60.10 & 15.06 & & & \\
\hline \multirow{2}{*}{ Son test } & HKG & 20 & 78.20 & 12.61 & 39 & -2.804 & .008 \\
& KG & 21 & 65.90 & 15.26 & & & \\
\hline
\end{tabular}

Tablo 1 incelendiğinde HKG'nin ön test sonuçlarının aritmetik ortalamasının 55.33, standart sapmasının ise 12.28 olduğu, KG'nin aritmetik ortalamasının 60.10, standart sapmasının ise 15.06 olduğu ve aralarındaki farkın anlamlı olmadığı görülmektedir $(t(39)=-1.107 ; p>0.05)$. HKG grubunun 


\section{Hikâye Kartlarının Çocukların Görsel İfade Becerileri Üzerindeki Etkisi}

son test sonuçlarının aritmetik ortalamasının 78.20, standart sapmasının ise 12.61 olduğu, KG'nin aritmetik ortalamasının 65.90 , standart sapmasının ise 15.26 olduğu ve aralarındaki farkın anlamlı bir farklılık oluşturduğu görülmektedir $(t(84)=-2.804 ; p<0.05)$. Çocukların bu uygulama yapmış oldukları resimlerde ortaya çıkan genel nitelikler Tablo 2'de verilmiştir.

Tablo 2. Mikropların dünyası adlı uygulamada çocukların resimlerine ilişkin genel nitelikler

\begin{tabular}{|c|c|c|}
\hline Grup & Uygulama öncesi & Uygulama sonrası \\
\hline HKG & $\begin{array}{l}\text { Çocuklar mikropları kötü olmayan, gülen } \\
\text { yüzlü ve sevimli karakterde çizmişlerdir. }\end{array}$ & $\begin{array}{l}\text { Hikâye kartlarından sonra çocuklar } \\
\text { hikâye bağlamında çizimlerini } \\
\text { gerçekleştirmişlerdir. Mikropları, kötü } \\
\text { görünümlü, hastalık yapıcı ve somurtkan } \\
\text { karakterde çizmişlerdir. }\end{array}$ \\
\hline KG & $\begin{array}{l}\text { Özellikle sabun gibi temizlik ürünleri } \\
\text { çizmişlerdir. }\end{array}$ & $\begin{array}{l}\text { Hikâye sonrasında çocuklar uygulama } \\
\text { öncesine benzer, fakat daha dikkatli } \\
\text { çizim yapmışlardır. }\end{array}$ \\
\hline
\end{tabular}

Bu uygulama sürecinde her iki grupta yer alan çocukların çizdikleri resimlere ait örnekler, Şekil 2 ve Şekil 3'te sunulmuştur.
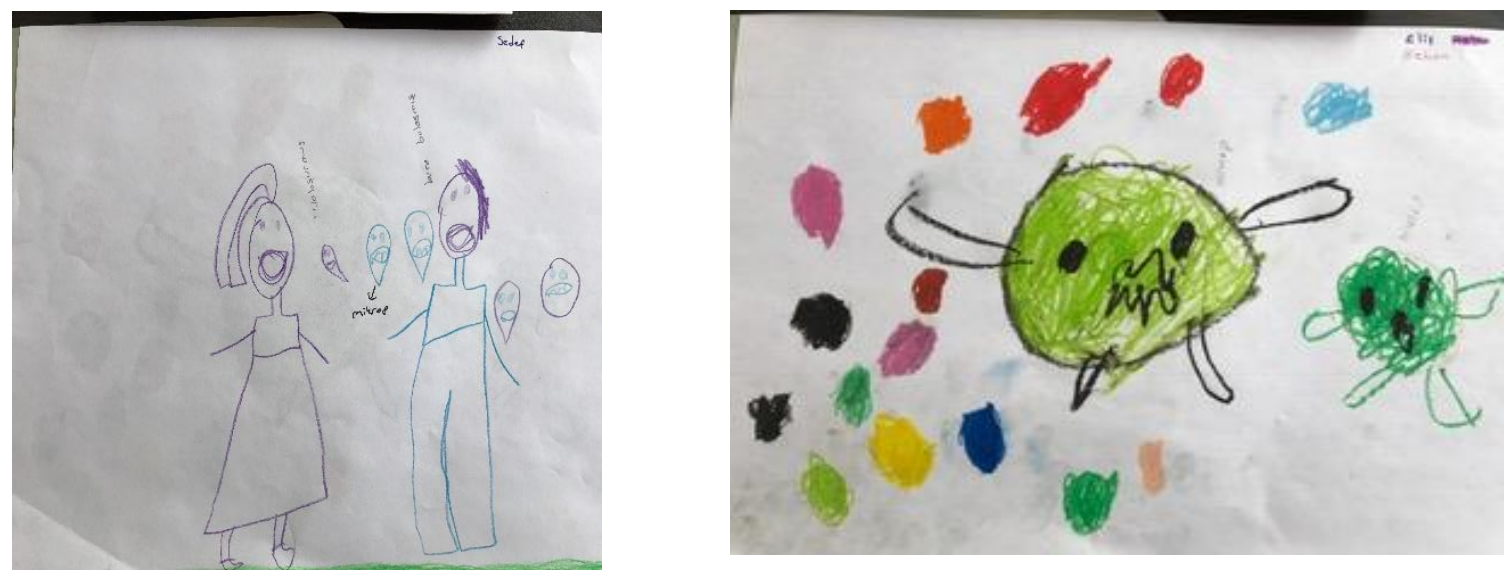

Şekil 2. HKG'de yer alan çocuklara ait son çizim örnekleri
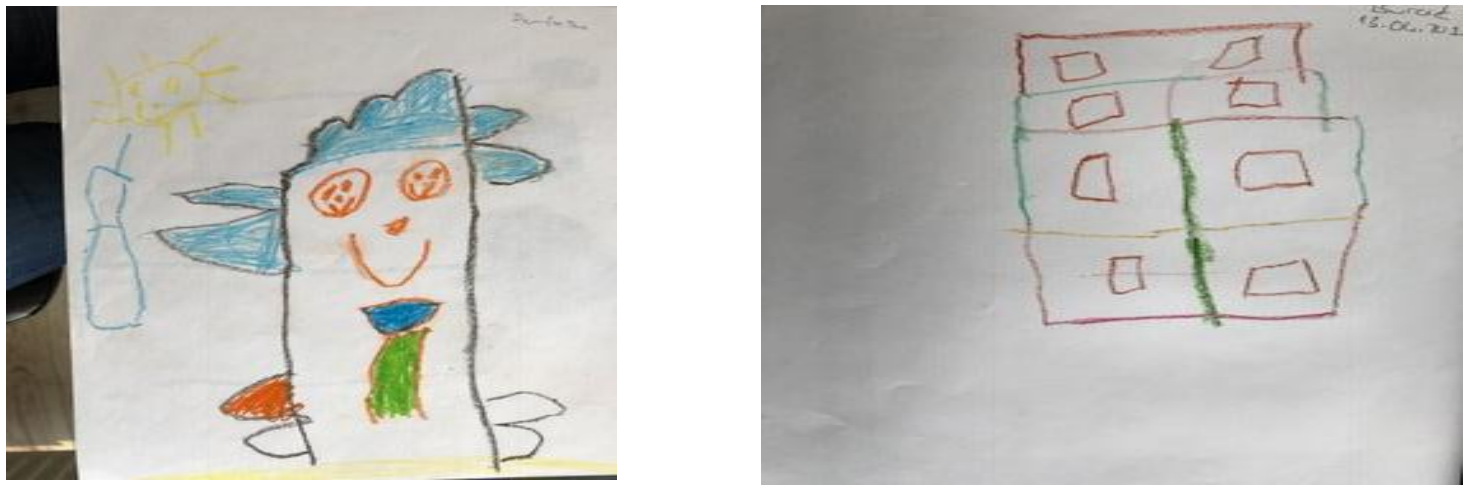

Şekil 3. $K G^{\prime}$ de yer alan çocuklara ait son çizim örnekleri 
Vitaminlerin Ziyareti adlı uygulamadan elde edilen bulgular

Çocukların "Vitaminlerin Ziyareti" adlı uygulama için hazırladıkları resimlerin ölçekten almış oldukları puanlara göre ön test ve son test ölçümleri Tablo 3'te verilmektedir.

Tablo 3. Gruplara göre ön test-son test bağımsız t testi sonuçları

\begin{tabular}{llllllll}
\hline Testler & Gruplar & $\mathbf{N}$ & $\mathbf{X}$ & $\mathbf{s s}$ & $\mathbf{s d}$ & $\mathbf{t}$ & $\mathbf{p}$ \\
\hline Ön test & HKG & 20 & 62.10 & 11.81 & 39 & -.507 & .615 \\
& KG & 21 & 60.28 & 11.10 & & & \\
\hline \multirow{2}{*}{ Son test } & HKG & 20 & 80.60 & 12.53 & 39 & -2.684 & .011 \\
& KG & 21 & 68.95 & 15.06 & & & \\
\hline
\end{tabular}

Tablo 3 incelendiğinde HKG'nin ön test sonuçlarının aritmetik ortalamasının 62.10, standart sapmasının ise 11.81 olduğu, KG'nin aritmetik ortalamasının 60.28 , standart sapmasının ise 11.10 olduğu ve aralarındaki farkın anlamlı olmadığı görülmektedir ( $t(39)=-.507 ; p>0.05)$. HKG grubunun son test sonuçlarının aritmetik ortalamasının 80.60 , standart sapmasının ise 12.53 olduğu, KG'nin aritmetik ortalamasının 68.95, standart sapmasının ise 15.06 olduğu ve aralarındaki farkın anlamlı bir farklılık oluşturduğu görülmektedir $(t(84)=-2.684 ; p<0.05)$. Çocukların bu uygulamada yapmış oldukları resimlerde ortaya çıkan genel nitelikler Tablo 4'te verilmiştir.

Tablo 4. Vitaminlerin ziyareti adlı uygulamada çocukların resimlerine ilişkin genel nitelikler

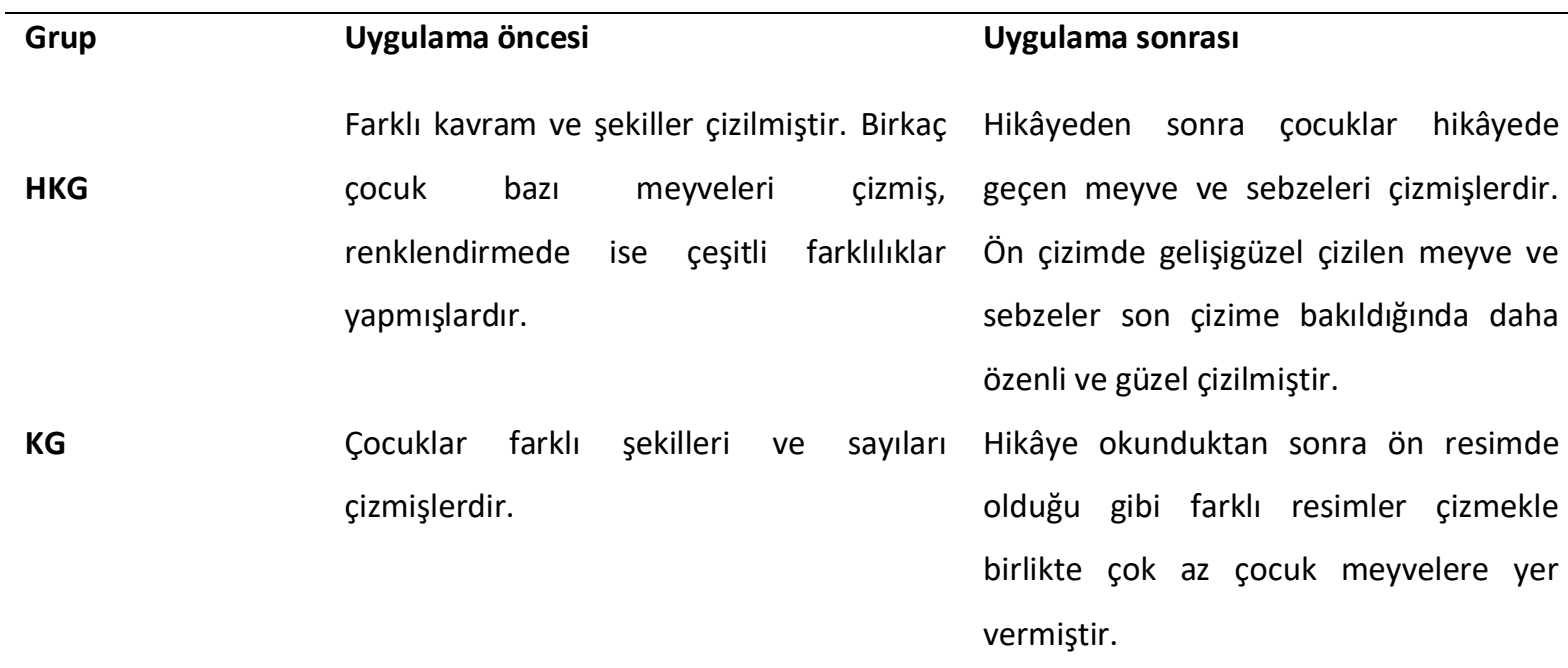


Bu uygulama sürecinde her iki grupta yer alan çocukların çizdikleri resimlere ait örnekler, Şekil 4 ve Şekil 5'te sunulmuştur.
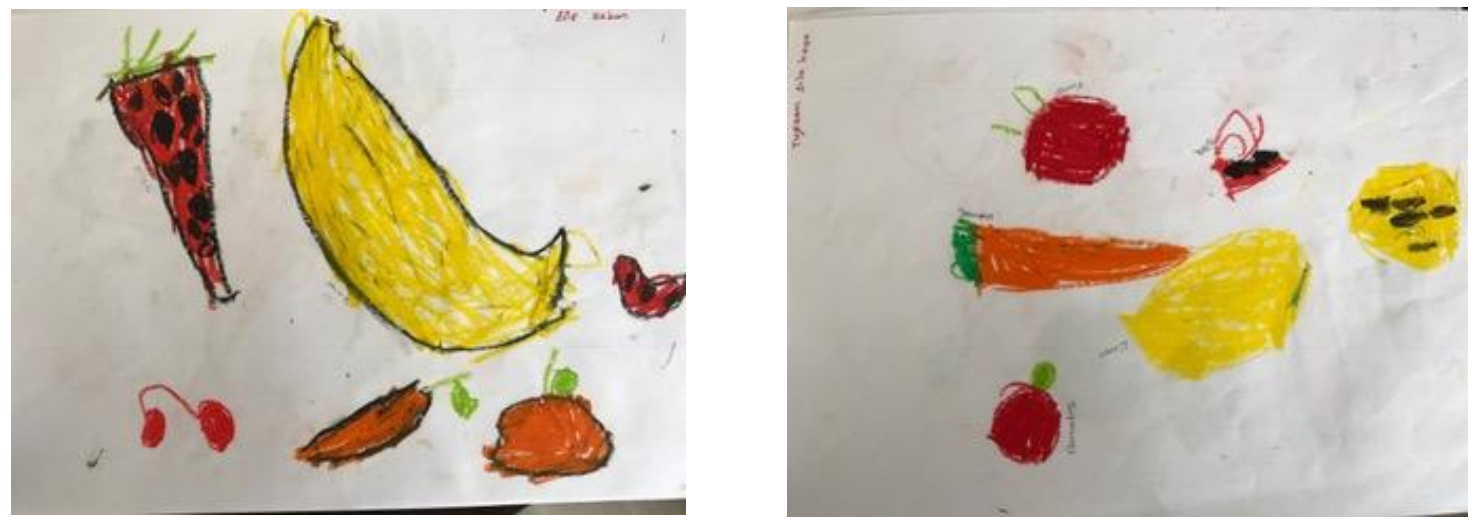

Şekil 4. HKG'de yer alan çocuklara ait son çizim örnekleri
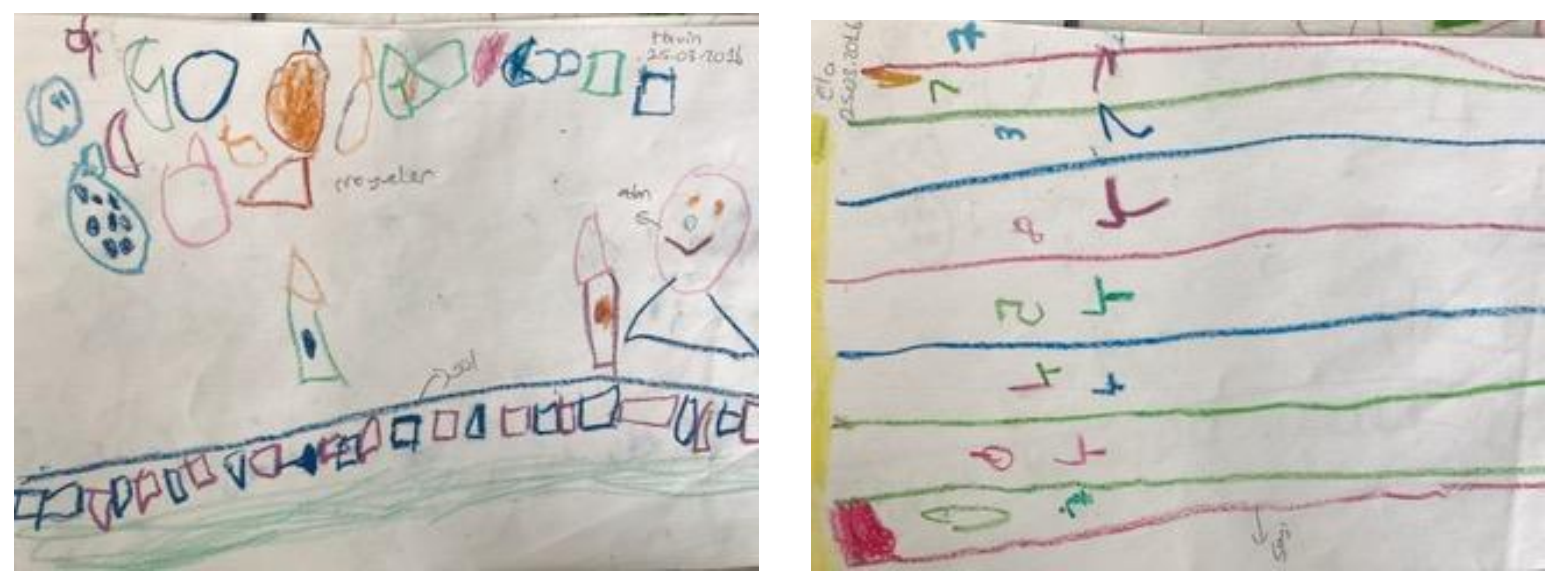

Şekil 5. KG'de yer alan çocuklara ait son çizim örnekleri

Duygularım adlı uygulamadan elde edilen bulgular

Çocukların "Duygularım" adlı uygulama için hazırladıkları resimlerin ölçekten almış oldukları puanlara göre ön test ve son test ölçümleri Tablo 5'te verilmektedir.

Tablo 5. Gruplara göre ön test-son test bağımsız $t$ testi sonuçları

\begin{tabular}{llcccccc}
\hline Testler & Gruplar & $\mathbf{N}$ & $\mathbf{X}$ & ss & sd & $\mathbf{t}$ & $\mathbf{p}$ \\
\hline \multirow{2}{*}{ Ön test } & HKG & 20 & 55.30 & 9.080 & 39 & -.285 & .777 \\
& KG & 21 & 54.57 & 7.086 & & & \\
\hline \multirow{2}{*}{ Son test } & HKG & 20 & 77.20 & 11.97 & 39 & .274 & .008 \\
& KG & 21 & 65.52 & 14.39 & & & \\
\hline
\end{tabular}


Tablo 5 incelendiğinde HKG'nin ön test sonuçlarının aritmetik ortalamasının 55.30, standart sapmasının ise 9.08 olduğu, KG'nin aritmetik ortalamasının 54.57, standart sapmasının ise 7.086 olduğu ve aralarındaki farkın anlamlı olmadığı görülmektedir $(t(39)=-.285 ; p>0.05)$. HKG grubunun son test sonuçlarının aritmetik ortalamasının 77.20, standart sapmasının ise 11.97 olduğu, KG'nin aritmetik ortalamasının 65.52, standart sapmasının ise 14.39 olduğu ve aralarındaki farkın anlamlı bir farklılık oluşturduğu görülmektedir $(t(84)=-.274 ; p<0.05)$. Çocukların bu uygulama yapmış oldukları resimlerde ortaya çıkan genel nitelikler Tablo 6'da verilmiştir.

Tablo 6. Duygularım adlı uygulamada çocukların resimlerine ilişkin genel nitelikler

\begin{tabular}{lll}
\hline Uygulama & Uygulama öncesi & Uygulama sonrası \\
HKG & Çocuklar her türlü yüz ifadesini & $\begin{array}{l}\text { Hikaye okunduktan sonra çocuklar } \\
\text { tamamen hikayeden farklı mutlu-mutsuz } \\
\text { çizmişlerdir. }\end{array}$ \\
& & $\begin{array}{l}\text { oldukları anı çizmişlerdir. Birkaçı dışında } \\
\text { hiçbir çocuk hikâyedeki kahramanları } \\
\end{array}$ \\
KG çizmemiştir.
\end{tabular}

Bu uygulama sürecinde her iki grupta yer alan çocukların çizdikleri resimlere ait örnekler, Şekil 6 ve Şekil 7'de sunulmuştur.
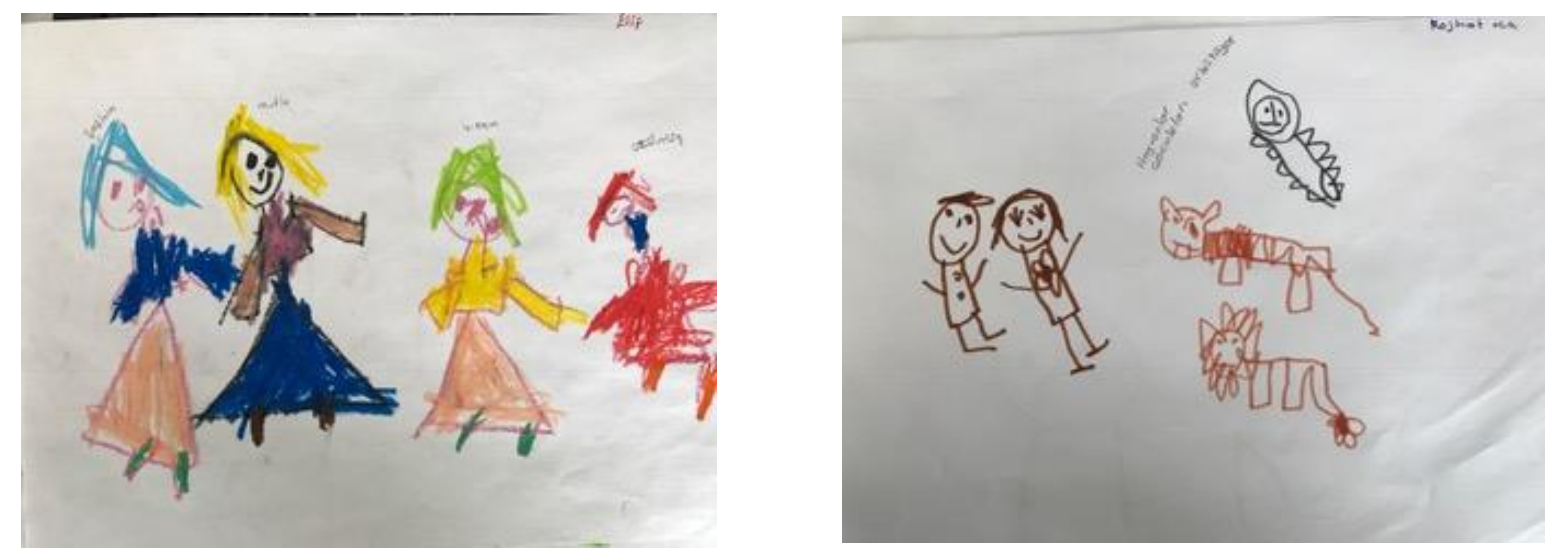

Şekil 6. HKG'de yer alan çocuklara ait son çizim örnekleri 

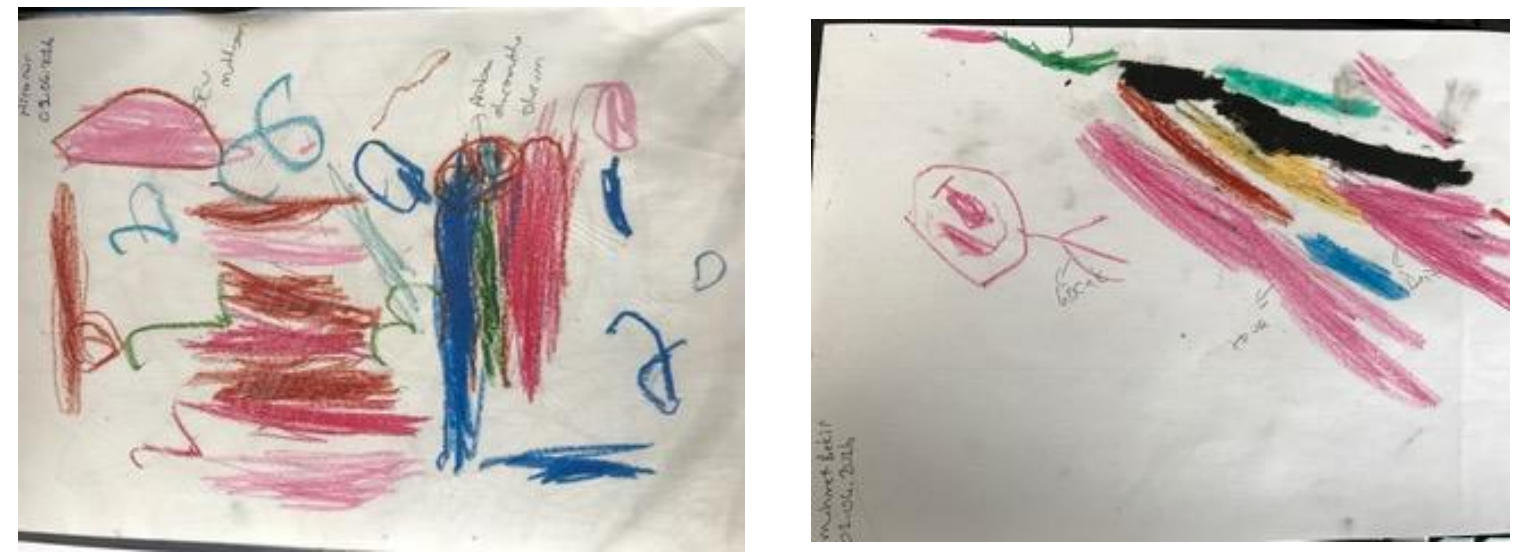

Şekil 7. KG'de yer alan çocuklara ait son çizim örnekleri

Suyun Yolculuğu adlı uygulamadan elde edilen bulgular

Çocukların "Suyun Yolculuğu" adlı uygulama için hazırladıkları resimlerin ölçekten almış oldukları puanlara göre ön test ve son test ölçümleri Tablo 7'de verilmektedir.

Tablo 7. Gruplara göre ön test-son test bağımsız t testi sonuçları

\begin{tabular}{llcccccc}
\hline Testler & Gruplar & $\mathbf{N}$ & $\mathbf{X}$ & ss & sd & $\mathbf{t}$ & $\mathbf{p}$ \\
\hline Ön test & HKG & 20 & 59.50 & 10.04 & 39 & -.348 & .730 \\
& KG & 21 & 58.38 & 10.51 & & & \\
\hline \multirow{2}{*}{ Son test } & HKG & 20 & 77.60 & 11.85 & 39 & -3.265 & .002 \\
& KG & 21 & 64.76 & 13.24 & & & \\
\hline
\end{tabular}

Tablo 7 incelendiğinde HKG'nin ön test sonuçlarının aritmetik ortalamasının 59.50, standart sapmasının ise 10.04 olduğu, KG'nin aritmetik ortalamasının 58.38, standart sapmasının ise 10.51 olduğu ve aralarındaki farkın anlamlı olmadığı görülmektedir $(t(39)=-.348 ; p>0.05)$. HKG grubunun son test sonuçlarının aritmetik ortalamasının 77.60 , standart sapmasının ise 11.85 olduğu, KG'nin aritmetik ortalamasının 64.76, standart sapmasının ise 13.24 olduğu ve aralarındaki farkın anlamlı bir farklılık oluşturduğu görülmektedir $(t(84)=-3.265 ; p<0.05)$. Çocukların bu uygulama yapmış oldukları resimlerde ortaya çıkan genel nitelikler Tablo 8'de verilmiştir.

Tablo 8. Suyun yolculuğu adlı uygulamada çocukların resimlerine ilişkin genel nitelikler

\begin{tabular}{lll}
\hline Uygulama & Uygulama öncesi & Uygulama sonrası \\
& Çocuklar çoğunlukla sıvı sabun ve musluk & Hikâye kartlarından sonra çocuklar \\
resimleri çizmiştir. & $\begin{array}{l}\text { kartlarda yer alan su damlası, buz küpleri } \\
\text { ve buhar resimlerini çizmişlerdir. }\end{array}$
\end{tabular}




\begin{tabular}{lll}
\hline KG Çocuklar çoğunlukla sıvı sabun ve musluk & $\begin{array}{l}\text { Çocuklardan bir kısmı hikaye bağlamında } \\
\text { resimleri çizmiştir. }\end{array}$ & sevdiği oyuncakları çizmiştir.
\end{tabular}

Bu uygulama sürecinde her iki grupta yer alan çocukların çizdikleri resimlere ait örnekler, Şekil 8 ve Şekil 9'da sunulmuştur.
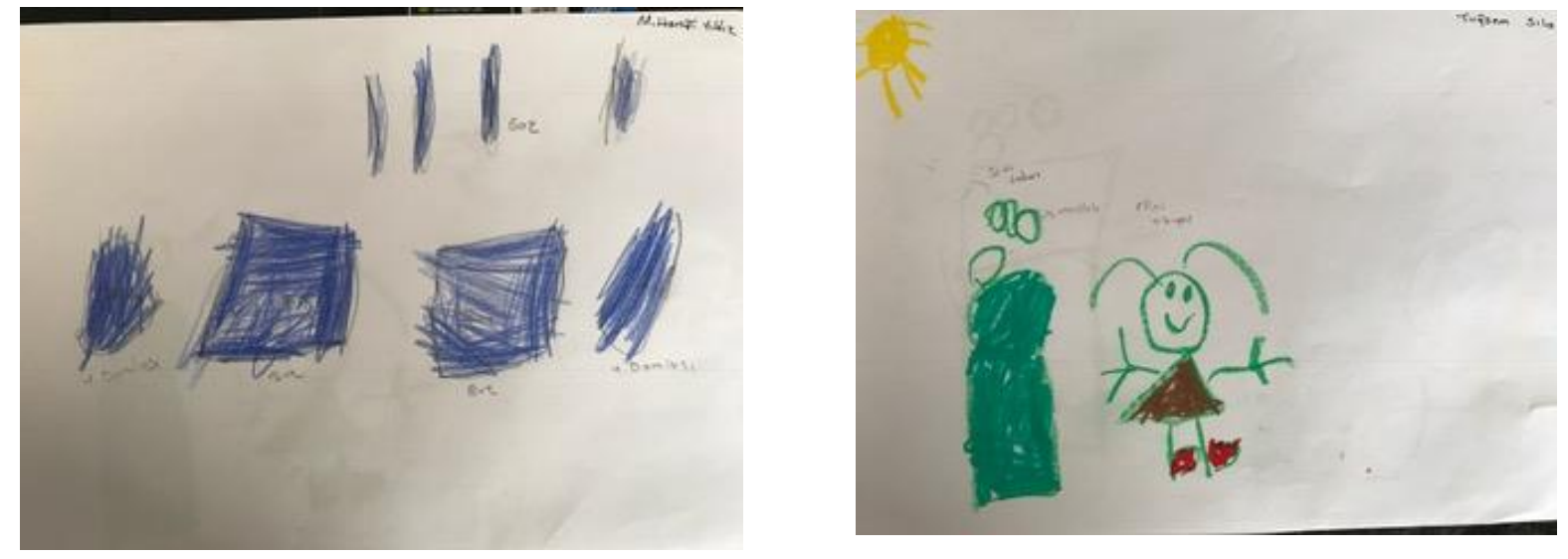

Şekil 8. HKG'de yer alan çocuklara ait son çizim örnekleri
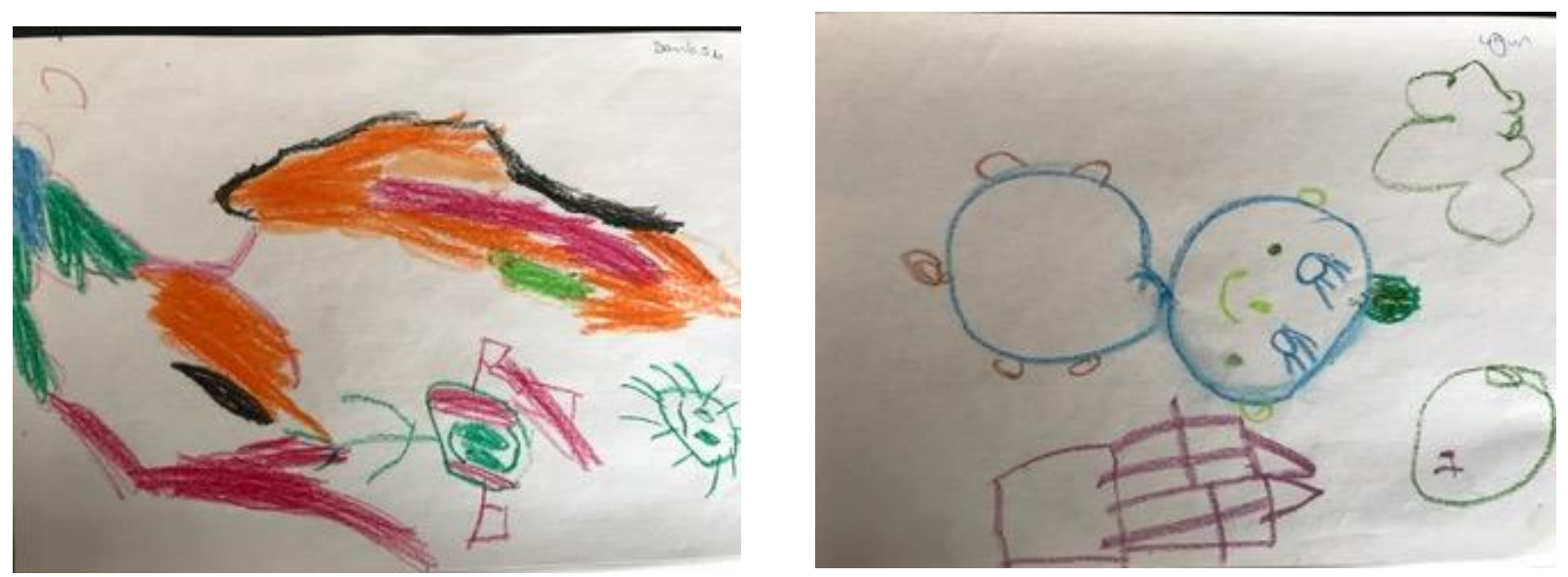

Şekil 9. $K G^{\prime}$ de yer alan çocuklara ait son çizim örnekleri

\section{Tartışma ve Sonuç}

Resimli hikâye kartlarının çocukların görsel ifade becerileri üzerindeki etkisinin belirlenmeye çalışıldığı bu çalışma sonucunda, soyut kavramları içeren fen konularının anlatımında hikâye kartlarının kullanımının çocukların görsel ifadelerine olumlu yönde etkide bulunduğu tespit edilmiştir. Okul öncesi çocuklarına hikâye anlatılmadan önce hikâyede yer alan kavramlarla ilgili çocukların çizimlerine bakıldığında, deney ve kontrol grupları arasında çizimlerin herhangi bir farklılık göstermediği, her iki gruptaki çocukların kavramlarla ilgili benzer düzey şemalara sahip olduğu belirlenmiştir. Ancak yapılan 4 farklı hikâye kartı uygulamasında da deney ve kontrol gruplarının 
hikâyelerden sonra çizdiği resimler arasında farklılıklar olduğu görülmüştür. Hikâye kartlarının kullanıldığı deney grubunda yer alan çocuklar, yaptıkları çizimlerde hikâye kartlarında yer alan imgeleri çizmeye çalışmışlar, resimleriyle hikâyedeki olayları adım adım bütünleştirmişlerdir. Kontrol grubunda yer alan çocukların anlatılan hikâyelerden sonra yapmış oldukları çizimler incelendiğinde ise, çocukların ilk yaptıkları resimler ile son yaptıkları resimler arasında belirgin farklar gözlenmemiş ve çocukların bağımsız olarak farklı objeler, kavramlar veya olayları resmettikleri sonucuna ulaşıımıştır. Araştırmada ortaya çıkan bu sonuç ile hikâye kartlarının çocuğa şema oluşturabilme, kavramları tanıyabilme ve olayları sıralayabilme becerisinin kazandırılmasında katkı yaptığı söylenebilir. Ayrıca çocukların hikâye bağlamında yapacakları resimlerin çocuğun sanatsal gelişimi üzerinde etkili olacağını ve çocukların estetik, algı ve yaratıcılıklarını geliştireceğini ifade etmek mümkündür (Çiçekler ve Koruklu, 2013).

Soyut ve karmaşık olan fen ve doğa konularının öğretiminde öğrencilerin seviyesine uygun somut araçların kullanılması gerekmektedir (Devecioğlu, Akdeniz ve Ayvacı, 2005; Osborne ve Freyberg, 1985; Turgut ve Gürbüz, 2011). Bu araçlardan biri hikâyeler olabilir. Fen bilimleri, yaşadığımız dünya ve kendi hakkımızdaki önemli ve ilginç olaylar ve buluşlarla ilgili hikâyelere sahiptir. Dolayısıyla hikâyeler mevcut programlarda yer alan ilişkili kavramların öğretiminde kullanılabilir (Demircioğlu, Demircioğlu ve Ayas, 2006). Bilimsel olgu ve olaylardan bilim insanlarının yaşamlarına kadar fen kavramlarının aktarımında öykülerden yararlanmak mümkündür (Banister ve Ryan, 2001; Coşkun, Akarsu ve Kariper, 2012; Gümüş, 2009). Okul öncesinde çocuklar hikâyelerden çıkarım yapma güçlerine sahiptirler (Tompkins, Guo ve Justice, 2013). Bu özelliklerinden ötürü çocuklara çokça soyut kavram içeren fen konularının aktarımında hikâyelerden yararlanılmalıdır (Brewer ve Bacon, 2001; Türkmen ve Ünver, 2012). Bununla birlikte hikâye kitaplarının çocukların anlamaları üzerinde daha etkili olması için, hikâye okuma etkinlikleri etkileşimli biçimde sürdürülmelidir (Wasik ve Bond, 2001).

Olay örüntüsünün ve soyut kavramların çok fazla olduğu fen konularında hikâye kartlarından yararlanılması öğretimin niteliğinin artmasını sağlayacaktır. Bu nedenle okul öncesi öğretmenlerinin hikâye kartlarına yer vermeleri, okul öncesi dönemde çocukların hızla gelişen kavram hazineleri açısından oldukça önemlidir. Çocuklar, hikâye aracılığıyla içine girdiği olay ve durum bağlamında öykü kişisi ile özdeşleşir, etkileşim yoluyla kendisini tanır ve değerlendirir; sosyal davranışlar kazanma, evrensel ilkeleri benimseme, çağdaş uygarlık değerleri ile tanışma; inanç, ilke ve davranışlarını sorgulama; bunun sonucunda onları değiştirebilme, ulusal değerleri tanıma ve özümseme ve bu sayede de toplumuyla uyum içinde olarak aidiyet duygusu geliştirme gibi onaylanan yetişkin özelliklerinin alt yapısını oluşturabilir (Bağdaş ve Demir, 2016; Uzmen ve Mağden,2002).

Hikâye okuma etkinlikleri sonrasında, çocuklara resim çizdirmek, çocukların çeşitli becerilerini değerlendirme açısından öğretmene yardımcı olmaktadır. Gönen ve arkadaşlarının (2010) yapmış 
oldukları çalışmada az sayıda okul öncesi öğretmeninin çizim yöntemini hikâyeden sonra kullandıklarını ortaya çıkarmıştır. Benzer şekilde Zülfikar (2004) tarafından yapılan çalışmada da okul öncesi öğretmenlerinin özellikle dil etkinliklerinde çocuklara hikâye okuma etkinlikleri yaptıkları belirlenmiştir. Eray Alışkan ve Güneyli (2016) tarafından yapılan çalışmaya göre ise okul öncesi öğretmenlerinin, dil etkinliklerinde hikâye kartlarını öykü kitapları kadar olmasa da sık sık kullandıkları belirlenmiştir. Bu araştırmalardan hareketle hikâye okuma etkinliklerinin, okul öncesi eğitimde sıklıkla kullanılan etkinlikler oldukları söylenebilir. Bu etkinliklerin bir kısmını hikâye kartları ile desteklemek çocukları çeşitli açılardan geliştirecektir. Hikâye kartları, çocukların hayal güçlerinin kuvvetlenmesinde, yaratıclıklarının gelişmesinde, boyama ve resim yapmaya ilgi ve heveslerinin artmasında, kelime hazinesi ve dil becerilerinin gelişmesinde, dinleme becerilerinin gelişmesinde, problem çözmeyi öğrenmelerinde, farklı düşünce ve duyguların ayırımına varmalarında ve duygudaşlıklarının gelişmesinde önemli rol oynayan araçlardır (Gönen vd. 2010). Bu bağlamda hikâye kartlarına okul öncesi eğitimde yer verilmesi gerektiği ifade edilebilir.

\section{Kaynaklar}

Akçay, H., Özyurt, B. B. ve Akçay, B. B. (2014). Çoklu yazma etkinliklerinin fen ve teknoloji dersi öğretiminde kullanılmasının öğrenci başarısı ve kavram öğrenmeye etkisi. Bayburt Üniversitesi Eğitim Fakültesi Dergisi, 9(2), 15-31.

Aksoy, P. ve Baran, G. (2010). 60-72 aylik çocukların okula ilişkin algılarının resim yoluyla incelenmesi. International Conference on New Trends in Education and Their Implications, 11-13 Kasım, Antalya, Turkey.

Aral, N., Kandır, A. ve Yaşar, M. C. (2000). Okul öncesi eğitim-2. İstanbul: YA-PA Yayıncılık.

Bağdaş, Ç. K.ve Demir, E. (2016). Okul öncesi öğretmenlerinin hikâye ve hikâye kitapları hakkındaki görüşlerinin incelenmesi (erzincan örneklemi). Erzincan Üniversitesi Sosyal Bilimler Enstitüsü Dergisi, ÖS-III, 219-230.

Banister, F. and Ryan, C. (2001). Developing science concepts through story-telling. School Science Review, 83(302), 75-83.

Bektaş, H. (2010). Okulöncesi öğretmenlerinin Türkçe dil etkinliklerinde kullandıkları hikâye anlatım yöntemlerinin incelenmesi: Karaman ili örneği. Yüksek lisans tezi, Selçuk Üniversitesi Eğitim Bilimleri Enstitüsü, Konya.

Brewer, J. A (2001). Introduction to early childhood education:preschool throught primary grades. Boston:Allyn and Bacon.

Cındıl, T., Özmen, H. ve Ünsal, S. (2012). 7. sınıf fen eğitiminde tansiyon kavramının hikâyeleş̧irme yöntemi ile öğretiminin öğrencilerin başarılarına ve bilgiyi yapılandırmalarına etkisi. $X$. Ulusal Fen Bilimleri ve Matematik Eğitimi Kongresi. 27-30 Haziran, Niğde Üniversitesi, Niğde.

Coşkun, H., Akarsu, B. ve Kariper, i. A. (2012). Bilim öyküleri içeren eğitsel oyunların fen ve teknoloji dersindeki öğrencilerin akademik başarılarına etkisi. Ahi Evran Üniversitesi Kırşehir Eğitim Fakültesi Dergisi (KEFAD), 13(1), 93-109.

Çağdaş, A., Albayrak, H. ve Cantekinler, S. (2003). Okul öncesi eğitimde dramatik etkinlikler. Konya: Eğitim Kitabevi.

Çınar, S. (2013). Okul öncesi öğretmenlerin fen ve doğa konularının öğretiminde kullandıkları etkinliklerin belirlenmesi. Eğitim ve Öğretim Araştırmaları Dergisi, 2(1), 364-371. 
Çiçekler, C. Y. ve Koruklu, N. Ö. (2013). 4-6 yaş arasındaki çocukların serbest resim çalışmalarındaki resim özellikleri. Hacettepe Üniversitesi Eğitim Fakültesi Dergisi, 28(2), 551-563.

Demircioğlu, H., Demircioğlu, G. ve Ayas, A. (2006). Hikâyeler ve kimya öğretimi. Hacettepe Eğitim Fakültesi becerileri kazandırmak için bir yaklaşım. Buca Eğitim Fakültesi Dergisi, 18, 64-72.

Doğru, S. S. Y., Turcan, A Dergisi, 30, 110-119.

Devecioğlu, Y., Akdeniz, A. R. ve Ayvacı, H. Ş. (2005). Okul öncesi öğretmen adaylarına fen öğretiminde rehber materyal geliştirme.i., Arslan, E. ve Doğru, S. (2006). Çocukların resimlerindeki aileyi tanılama durumlarının değerlendirilmesi. Selçuk Üniversitesi Sosyal Bilimler Enstitüsü Dergisi, 15, 223-235.

Ekici, F. A. ve Pekmezci, S. (2013). Bilişim teknolojileri destekli hikâyelerin fen ve teknoloji dersindeki öğrenci başarılarına etkisi. International Symposium on Changes and New Trends Education, 22-24 November, Necmettin Erbakan University, Konya.

Eray Alışkan, E. ve Güneyli, A. (2016) Okul öncesi öğretmenlerinin Türkçe dil etkinliklerine ilişkin görüşleri: Lefkoşa örneği. Ana Dili Eğitimi Dergisi, 4(3), 348-371.

Gönen, M., Ünüvar, P., Bıçakçı, M., Koçyiğit, S., Yazııı, Z., Orçan, M., Aslan, D., Güven, G. ve Özyürek, A. (2010). Okul öncesi eğitim öğretmenlerinin dil etkinliklerini uygulama biçimlerinin incelenmesi. Mehmet Akif Ersoy Üniversitesi Eğitim Fakültesi Dergisi, 19, 23-40.

Gümüş, B. Ş. (2009). Bilimsel öykülerle fen ve teknoloji eğitiminin öğrencilerin fen tutumlarına ve bilim insanı imajlarına etkisi. Yayınlanmamış Yüksek Lisans Tezi, Hacettepe Üniversitesi, Ankara.

Kahraman, F. ve Karataş, F. Ö. (2012). Bilim tarihi temelli hikâyeler kullanımı ile 7. sınıf "basit makineler" konusunun öğretimi: bir eylem araştırması. X. Ulusal Fen Bilimleri ve Matematik Eğitimi Kongresi. 2730 Haziran, Niğde Üniversitesi, Niğde.

Karweit, N. ve Wasik, B. A. (1996). The effects of story reading programs on literacy and language development of disadvantaged preschoolers. Journal of Education for Students Placed at Risk (JESPAR), 1(4), 319348.

Küçükturan, G. (2004). Öykülerle öğreniyorum. Ankara: SMG Yayıncılık.

Okur Akçay, N. (2014). Zıt kavramların öğretilmesinde birlikte öğrenme yönteminin etkisi. Eğitim ve Öğretim Araştırmaları Dergisi, 3(1), 398-405.

Osborne, R.and Freyberg, P. (1985). Children's Science. In R. OSBORNE and P. FREYBERG (Eds.) Learning in Science: The implications of children's science, (pp.5-14). Hong Kong: Heinemann.

Ömeroğlu, E. ve Yaşar, M.C. ( 2005). Okul öncesi eğitim kurumlarında ailenin eğitime katıılımı. Bilim ve Aklın Aydınlığında Eğitim, 6 (62).

Ören, F. Ş. ve Yılmaz, T. (2013). Fen ve teknoloji dersinde kavram karikatürleriyle desteklenmiş bilimsel hikâyeler temelli rehber materyal geliştirme çalışması. Eğitim ve Öğretim Araştırmaları Dergisi, 2(2), 130-141.

Özmen, H. ve Kolomuç, A. (2004). Bilgisayarlı öğretimin çözeltiler konusundaki öğrenci başarısına etkisi. Kastamonu Eğitim Dergisi, 12(1), 57-68.

Robson, C. (1998). Real world research. Oxford: Blackwell Publishers.

Saatli, G. (1997). Okul öncesi eğitim kurumlarında ana dili etkinlikleri. Ankara: Mesleki ve Teknik Eğitimi Geliştirme Projesi.

Şahin, H. (2016). Okul öncesi fen eğitiminde analoji yöntemi ve analojinin okul öncesi eğitim programlarında yer alma düzeyi. Uluslararası Türk Eğitim Bilimleri Dergisi, 4(6), 48-62.

Tao, P. (2002). A study of students focal awareness when studying science stories designed for fostering understanding of the nature of science. Research in Science Education, 32(1), 97-120.

Tompkins,V., Guo, Y. ve Justice, L. M. (2013). Inference generation, story comprehension, and language skills in the preschool years. Reading and Writing, 26(3), 403-429. 
Turgut, G. ve Kışla T. (2015). Bilgisayar destekli hikâye anlatım yöntemi: alanyazın araştırması. Turkish Online Journal of Qualitative Inquiry, 6(2), 97-121.

Turgut, Ü. ve Gürbüz, F. (2011). Fen öğretiminde öğrenme kuramları ve laboratuvar destekli yapılandırmacı (constructivist) öğrenme kuramı. Trakya Üniversitesi Eğitim Fakültesi Dergisi, 1(2), 45-78.

Türkmen, H. ve Ünver, E. (2012). Fen eğitiminde hikayelendirme tekniği. Journal of European Education, 2(1), 913.

Ural, M. (1985). Altı yaş grubu öğretmen kılavuzu. Ankara: Milli Eğitim Gençlik ve Spor Bakanlığı Yayınları.

Uzmen, S. ve Mağden, D. (2002). Okulöncesi eğitim kurumlarına devam eden altı yaş çocuklarının prososyal davranışlarının resimli çocuk kitapları ile desteklenmesi. M.Ü. Atatürk Eğitim Fakültesi Eğitim Bilimleri Dergisi, 15,193-212.

Wasik, B.A. ve Bond, M. A. (2001). Beyond the pages of a book: Interactive book reading and language development in preschool classrooms. Journal of Educational Psychology, 93(2) 243-250.

Yaşar, Ş. (1993). Okul öncesi eğitim öğrencilerinde fene yönelik duyuşsal özellikler. 9. Ya-pa Okul Öncesi Eğit. ve Yay. Semineri, Ankara.

Zembat, R. ve Zülfikar, S. (2006). Okul öncesi öğretmenlerinin sohbet ve hikâye etkinliklerinde kullandıkları öğretim yöntemlerinin incelenmesi. Educational Sciences: Theory \& Practice, 6(2), 587-608.

Zülfikar, T. (2004). Okul öncesi eğitim etkinliklerinde kullanılan öğretim yöntemlerinin ve tekniklerinin incelenmesi. Yayımlanmamış Yüksek Lisans Tezi, Marmara Üniversitesi, İstanbul. 